\title{
Electrolyte changes of serum and muscle, and related mortalities in maturing Anguilla rostrata migrating down the St. Lawrence Estuary (Canada)
}

\author{
J.-D. Dutil \\ Government of Canada, Department of Fisheries and Oceans, \\ Fisheries Research Branch, Gare maritime Champlain; \\ 901 Cap Diamant, Québec, Québec G1K 7Y7, Canada
}

\begin{abstract}
This study was made to investigate changes in serum and muscle ion concentrations and related mortalities in maturing Anguilla rostrata migrating down the St. Lawrence Estuary. Mortalities take place in the freshwater portion of the St. Lawrence. Electrolyte concentrations of moribund eels taken in freshwater were compared to those of freshwater and salt water controls. Moribund eels had a much lower serum osmolality $(270 \mathrm{mOsm} / \mathrm{kg}$ ) than the controls ( 328 and 358 $\mathrm{mOsm} / \mathrm{kg})$. This resulted from low sodium $(125 \mathrm{mEq} / \mathrm{l})$ and particularly low chloride $(69 \mathrm{mEq} / \mathrm{l})$ contents in the moribund eels compared to the freshwater controls (153 and $117 \mathrm{mEq} / \mathrm{l}$ ) and the salt water controls (179 and $137 \mathrm{mEq} / 1$ ). There was also a general decrease in muscle ion concentrations in moribund eels though the percentage water was similar to that of the freshwater controls $(64.0$ and $63.7 \%$ ). The changes measured between the freshwater controls and the salt water controls in nature are similar to those measured on Anguilla anguilla in laboratory. These results suggest that mortalities are related to failure by some of the maturing eels to maintain their mineral balance in freshwater. Hypothesis is made that maturing eels migrating long distances in freshwater or retarded by physical or chemical barriers, start to excrete sodium and chloride under hormonal control before they have reached brackish water. In the conditions that prevail in the St. Lawrence Estuary, this results in mineral unbalance and possibly in mortalities.
\end{abstract}

\section{INTRODUCTION}

This study was made to investigate changes in the serum and muscle ion concentration and related mortalities in maturing Anguilla rostrata migrating down the St. Lawrence River. The distribution of the catadromous eel in the St. Lawrence watershed is extensive. Maturing eels migrating to the sea are harvested by commercial fishermen, particularly in the Richelieu River and in the St. Lawrence River from Lake St. Pierre to Rimouski (Fig. 1). Harvesting starts in spring in Lake St. Pierre and closes in autumn in Rimouski. From 1960 to 1980 , the mean annual catch in Quebec was 450 metric tons, nearly $70 \%$ of the total catch in Canada.

Throughout the harvesting season, but more particularly in late summer, heavy eel mortalities take place in the St. Lawrence. Fishermen catch moribund eels that cannot be sold to marketing plants. Hundreds of eels are stranded on the beaches. Fishermen believe this phenomenon goes back at least to the $1960^{\circ} \mathrm{s}$. The maximum intensity was 
reached between 1972 and 1974 . Nevertheless, it is recurring and that is of concern to the industry.

Hypotheses to be tested stemmed from three main considerations. The St. Lawrence River is polluted. Thus, pollution cannot be ruled out as partially contributing to mortality. However, based on the presence and the immunity of more than 20 species of fish in that stretch of the St. Lawrence, including the salmon (Salmo salar) that is most sensitive to pollution, pollution alone is not a likely cause. Particularly relevant is the observation that the mortality hits the maturing eels exclusively though immature eels are also present in that stretch of the St. Lawrence. Finally, the mortality has never been reported from brackish water. Thus three potential causes have been considered: bacterial infection, viral infection, and physiological stress related to the processes of maturation and migration. Bacteria have been ruled out as a potential cause (Dutil \& Lallier, in prep.). Investigations on viruses are in progress. This paper examines the possibility that physiological disorders related to the processes of maturation and to the passage from freshwater to salt water, measured as changes in the concentrations of electrolytes in the serum and the muscle, lead to such mortalities in the conditions that prevail in the St. Lawrence River.

\section{MATERIAL AND METHODS}

Samples from freshwater were collected in a commercial weir near St. Nicolas in the summer and fall of 1981 and 1982 (Fig. 1). St. Nicolas is located $50 \mathrm{~km}$ from the highest point of penetration of salt water in the St. Lawrence Estuary. Samples from brackish water were collected in a commercial weir near Kamouraska in the fall of 1981 (Fig. 1). Kamouraska is located $100 \mathrm{~km}$ downstream from the highest point of penetration of salt water. Salinity ranges from $0 \%$ at St. Nicolas to $22 \%$ at Kamouraska.

St. Nicolas samples included both diseased and healthy eels. Diseased eels are recognizable by their loss of skin pigmentation, lack of reaction to touch and lack of

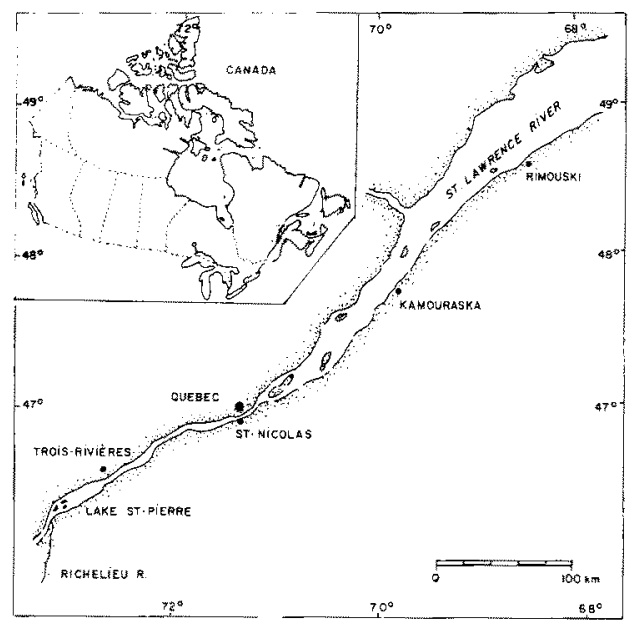

Fig. 1. Location of the collecting sites in St. Lawrence Estuary 
coordination. There are no means to recognize earlier stages in the disease. Thus, several moribund eels died as they were being transported to the laboratory. Kamouraska samples included healthy eels exclusively as there are no known instances of mortality in this location. Transportation to the laboratory took less than $2 \mathrm{~h}$ in all cases.

In the laboratory, the eels were anaesthetized in a solution of methyl pentynol (1 to $2 \mathrm{ml}$ per $\mathrm{l}$ ). Length $(\mathrm{mm})$ and mass $(\mathrm{g})$ were measured. Samples of blood $(5 \mathrm{ml})$ were taken from the dorsal aorta near the heart. Blood was allowed to clot and then was centrifuged. No blood was taken from those diseased eels that died in transportation. Part of the gonad was dissected out, fixed in Bouin's solution and dehydrated in methanol. Tissues were then embedded in paraffin and $8 \mu \mathrm{m}$ slices were prepared on a rotatory microtome. Slices were stained with hematoxylin and counter-stained with phloxine. Sections were mounted on a slide and examined microscopically to determine the sex and state of maturity. The stomach and intestine were examined for food.

Specific electrodes (Technicon Simultaneous Multiple Analysis Computer) were used to measure the serum concentrations of sodium, chloride, calcium, and potassium. Magnesium concentration was measured by photometry (Perkin Elmer Atomic Absorption Spectrophotometer Model 360). Osmolality was measured with an osmometer (Advanced Instruments Osmometer Model 3L). Ion concentrations are expressed in milliequivalents per liter.

Parietal muscle was dissected from the dorsal part of the fish taking care to remove the skin and bones. Moisture content was measured on a 10 to $20 \mathrm{~g}$ muscle sample dried at $60^{\circ} \mathrm{C}$ till constant weight was achieved. Concentrations of sodium, calcium, potassium and magnesium were determined by photometry (Perkin Elmer Atomic Absorption Spectrophotometer Model 603). Muscle chloride was calculated from the percentage of muscle sodium chloride as determined by the silver nitrate method. Results are expressed in milliequivalents per kilogram of water.

Statistical tests included the Kruskal-Wallis analysis of variance and the MannWhitney U-test (Siegel, 1956). Parametric tests could not be carried out due to heterogeneity of the variances.

\section{RESULTS}

Though the three categories of eels differed in mean length and mean weight $(\alpha=.01)$ (Table 1$)$, they were all exclusively composed of females. These had maturing

Table 1. Mean size of the maturing eels collected in St. Nicolas and Kamouraska

\begin{tabular}{|c|c|c|c|}
\hline Eels & Length (mm) & Weight (g) & Number of samples \\
\hline $\begin{array}{l}\text { St. Nicolas } \\
\text { (Moribund eels) }\end{array}$ & $845 \pm 110$ & $1390 \pm 611$ & 46 \\
\hline $\begin{array}{l}\text { St. Nicolas } \\
\text { (Freshwater controls) }\end{array}$ & $754 \pm 53$ & $831 \pm 181$ & 40 \\
\hline $\begin{array}{l}\text { Kamouraska } \\
\text { (Salt water controls) }\end{array}$ & $916 \pm 77$ & $1711 \pm 534$ & 41 \\
\hline
\end{tabular}


gonads as confirmed by microscopic examination of gonadal tissues. Furthermore, there was no food to be found in the stomachs or the intestines as is to be expected from migrating eels. Results are presented in Table 2 and Table 3. Data for 1981 and 1982 have been pooled as there was no statistical difference between years $(\alpha<.002)$.

\section{Passage from freshwater to salt water (controls)}

Passage of maturing eels from freshwater to salt water resulted in a marked increase in serum and muscle sodium (18 and $26 \%$ ) and chloride (18 and $45 \%$ ). Potassium concentration decreased in the blood from 2.6 to $2.2 \mathrm{mEq} / 1$ (this is not statistically significant) but increased in muscle by $20 \%$. The concentration of magnesium increased in the blood (more than $30 \%$ ) while the concentration of this ion in muscle remained remarkably constant at $6.2 \mathrm{mEq} / \mathrm{l}$. Finally, the concentration of calcium increased in the serum $(5.8 \%$ ) and decreased in the muscle from a high of $4.4 \mathrm{mEq} / 1$ in freshwater to a low of $3.4 \mathrm{mEq} / 1$ in salt water.

These changes resulted in an increase in serum osmolality from 328 to $358 \mathrm{mOsm} /$ $\mathrm{kg}$. Muscle water content decreased by $2 \%(\alpha<.012)$ (Table 4$)$. The $\mathrm{Na}: \mathrm{K}$ ratio markedly increased and the $(\mathrm{Na}+\mathrm{K}): \mathrm{Ca}$ and $(\mathrm{Na}+\mathrm{K}):(\mathrm{Ca}+\mathrm{Mg})$ ratios barely increased in the serum. The situation is reversed in muscle where the latter two ratios increased and the $\mathrm{Na}$ : $\mathrm{K}$ ratio remained constant (Table 5 and Table 6).

Table 2. Mean, standard deviation and range of serum electrolyte concentrations in three categories of maturing eels, freshwater controls (FC), sea water controls (SC) and moribund eels (FM), and probability levels of homogeneous means or distributions between these categories

\begin{tabular}{|c|c|c|c|c|c|c|c|}
\hline Parameter & FC & SC & FM & $\begin{array}{c}\text { Kruskal } \\
\text { Wallis } \\
\text { FC-SC-FM }\end{array}$ & $\begin{array}{l}\text { Mann- } \\
\text { FC-SC }\end{array}$ & FC-FM & $\begin{array}{l}\text { U-test } \\
\text { SC-FM }\end{array}$ \\
\hline $\begin{array}{l}\mathrm{Na}^{+} \\
\mathrm{mEq} / 1\end{array}$ & $\begin{array}{c}152.6 \pm 26.2 \\
(40-168) \\
38\end{array}$ & $\begin{array}{c}179.3 \pm 6.5 \\
(156-192) \\
41\end{array}$ & $\begin{array}{c}124.9 \pm 18.0 \\
(105-168) \\
27\end{array}$ & $<.001$ & $<.0001$ & $<.0001$ & $<.0001$ \\
\hline $\begin{array}{l}\mathrm{Cl}^{-} \\
\mathrm{mEq} / 1\end{array}$ & $\begin{array}{c}116.7 \pm 22.6 \\
(15-134) \\
39\end{array}$ & $\begin{array}{c}137.4 \pm 7.1 \\
(112-149) \\
41\end{array}$ & $\begin{array}{c}69.3 \pm 22.3 \\
(42-118) \\
26\end{array}$ & $<.001$ & $<.0001$ & $<.0001$ & $<.0001$ \\
\hline $\begin{array}{l}\mathrm{K}^{+} \\
\mathrm{mEq} / \mathrm{l}\end{array}$ & $\begin{array}{c}2.60 \pm 1.50 \\
(0.4-5.6) \\
38\end{array}$ & $\begin{array}{c}2.21 \pm 1.09 \\
(0.5-5.6) \\
41\end{array}$ & $\begin{array}{c}5.77 \pm 2.68 \\
(0.9-13.4) \\
27\end{array}$ & $<.001$ & .3614 & $<.0001$ & $<.0001$ \\
\hline $\begin{array}{l}\mathrm{Mg}^{++} \\
\mathrm{mEq} / 1\end{array}$ & $\begin{array}{c}3.297 \pm 0.437 \\
(1.98-4.15) \\
39\end{array}$ & $\begin{array}{c}4.390 \pm 0.505 \\
(2.90-5.07) \\
40\end{array}$ & $\begin{array}{c}3.696 \pm 0.834 \\
(2.79-6.38) \\
27\end{array}$ & $<.001$ & $<.0001$ & .1532 & $<.0001$ \\
\hline $\begin{array}{l}\mathrm{Ca}^{++} \\
\mathrm{mEq} /\end{array}$ & $\begin{array}{c}13.69 \pm 2.73 \\
(6.0-21.4) \\
40\end{array}$ & $\begin{array}{c}14.49 \pm 1.98 \\
(8.1-19.7) \\
41\end{array}$ & $\begin{array}{c}13.72 \pm 1.69 \\
(10.8-17.5) \\
27\end{array}$ & $<.050$ & .0352 & .6744 & .0870 \\
\hline $\begin{array}{l}\text { Osmolality } \\
\mathrm{mOsm} / \mathrm{kg}\end{array}$ & $\begin{array}{c}327.9 \pm 19.4 \\
(300-406) \\
35\end{array}$ & $\begin{array}{c}358.3 \pm 12.4 \\
(324-379) \\
41\end{array}$ & $\begin{array}{c}269.9 \pm 32.6 \\
(217-334) \\
23\end{array}$ & $<.001$ & $<.0001$ & $<, 0001$ & $<.0001$ \\
\hline
\end{tabular}


Table 3. Mean, standard deviation and range of muscle electrolyte concentrations in three categories of maturing eels, freshwater controls (FC), sea water controls (SC) and moribund eels (FM), and probalility levels of homogeneous means or distributions between these categories

\begin{tabular}{|c|c|c|c|c|c|c|c|}
\hline \multirow[t]{2}{*}{ Parameter } & \multirow[t]{2}{*}{ FC } & \multirow[t]{2}{*}{$\mathrm{SC}$} & \multirow[t]{2}{*}{ FM } & \multirow{2}{*}{$\begin{array}{c}\text { Kruskal } \\
\text { Wallis } \\
\text { FC-SC-FM }\end{array}$} & \multicolumn{3}{|c|}{ Mann-Whitney U-test } \\
\hline & & & & & FC-SC & FC-FM & SC-FM \\
\hline $\begin{array}{l}\mathrm{Na}^{+} \\
\mathrm{mEq} / \mathrm{kg}\end{array}$ & $\begin{array}{c}23.4 \pm 6.1 \\
(16.4-42.3) \\
40\end{array}$ & $\begin{array}{c}29.6 \pm 6.9 \\
(16.8-41.6) \\
39\end{array}$ & $\begin{array}{c}21.2 \pm 3.9 \\
(14.4-30.0) \\
27\end{array}$ & $<.001$ & .0002 & .3918 & $<.0001$ \\
\hline $\begin{array}{l}\mathrm{Cl}^{-} \\
\mathrm{mEq} / \mathrm{kg}\end{array}$ & $\begin{array}{c}29.1 \pm 5.4 \\
(20.9-43.2) \\
40\end{array}$ & $\begin{array}{c}42.3 \pm 4.2 \\
(33.1-50.8) \\
39\end{array}$ & $\begin{array}{c}38.1 \pm 13.0 \\
(15.5-62.6) \\
27\end{array}$ & $<.001$ & $<.0001$ & .0008 & .0202 \\
\hline $\begin{array}{l}\mathrm{K}^{+} \\
\mathrm{mEq} / \mathrm{kg}\end{array}$ & $\begin{array}{c}86.7 \pm 10.3 \\
(68.3-111.3) \\
40\end{array}$ & $\begin{array}{c}103.7 \pm 14.9 \\
(78.1-132.4) \\
39\end{array}$ & $\begin{array}{c}71.6 \pm 14.0 \\
(52.2-108.9) \\
27\end{array}$ & $<.001$ & $<.0001$ & $<.0001$ & $<.0001$ \\
\hline $\begin{array}{l}\mathrm{Mg}^{++} \\
\mathrm{mEq} / \mathrm{kg}\end{array}$ & $\begin{array}{c}6.2 \pm 0.9 \\
(3.9-9.4) \\
40\end{array}$ & $\begin{array}{c}6.2 \pm 0.7 \\
(4.4-7.6) \\
39\end{array}$ & $\begin{array}{c}4.8 \pm 1.3 \\
(2.5-10.1) \\
27\end{array}$ & $<.001$ & .7836 & $<.0001$ & $<.0001$ \\
\hline $\begin{array}{l}\mathrm{Ca}^{++} \\
\mathrm{mEq} / \mathrm{kg}\end{array}$ & $\begin{array}{c}4.4 \pm 1.1 \\
(1.9-7.0) \\
40\end{array}$ & $\begin{array}{c}3.4 \pm 1.8 \\
(0.2-8.3) \\
39\end{array}$ & $\begin{array}{c}4.0 \pm 1.2 \\
(1.5-7.7) \\
27\end{array}$ & $<.010$ & .0016 & .1158 & .0876 \\
\hline
\end{tabular}

Table 4. Muscle water content $(\%)$ in three categories of maturing eels: freshwater controls (FC), sea water controls (SC) and moribund eels (FM)

\begin{tabular}{|cccc|}
\hline Category & Mean & Range & Number of eels \\
\hline FC & $63.7 \pm 2.5$ & $61.2-66.2$ & 40 \\
SC & $61.8 \pm 3.6$ & $58.2-65.4$ & 39 \\
FM & $64.0 \pm 6.0$ & $58.0-70.0$ & 27 \\
\hline
\end{tabular}

\section{Moribund eels}

Electrolyte concentrations in the moribund eels differed markedly from those of the freshwater controls. This is reflected by their having a lower serum osmolality (270 $\mathrm{mOsm} / \mathrm{kg})$ than the freshwater controls $(328 \mathrm{mOsm} / \mathrm{kg})$. This $30 \%$ variation resulted from low sodium and low chloride contents in moribund eels. There was a concurrent increase in potassium concentration from 2.6 to $5.8 \mathrm{mEq} / 1$ in moribund eels. There was no statistical difference in the serum magnesium and calcium concentrations between the controls and the moribund eels.

There were also variations in muscle ion concentrations. No variation took place in muscle sodium concentration, but the chloride concentration was much higher in moribund eels than in freshwater controls: $38.1 \mathrm{mEq} / 1$ and $29.1 \mathrm{mEq} / \mathrm{l}$ respectively. That value was close to the high $42.3 \mathrm{mEq} / 1$ for salt water controls. Potassium and magnesium 
Table 5. Mean, standard deviation and range of serum electrolyte ratios in three categories of maturing eels, freshwater controls (FC), sea water controls (SC) and moribund eels (FM), and probability levels of homogeneous means or distributions between these categories

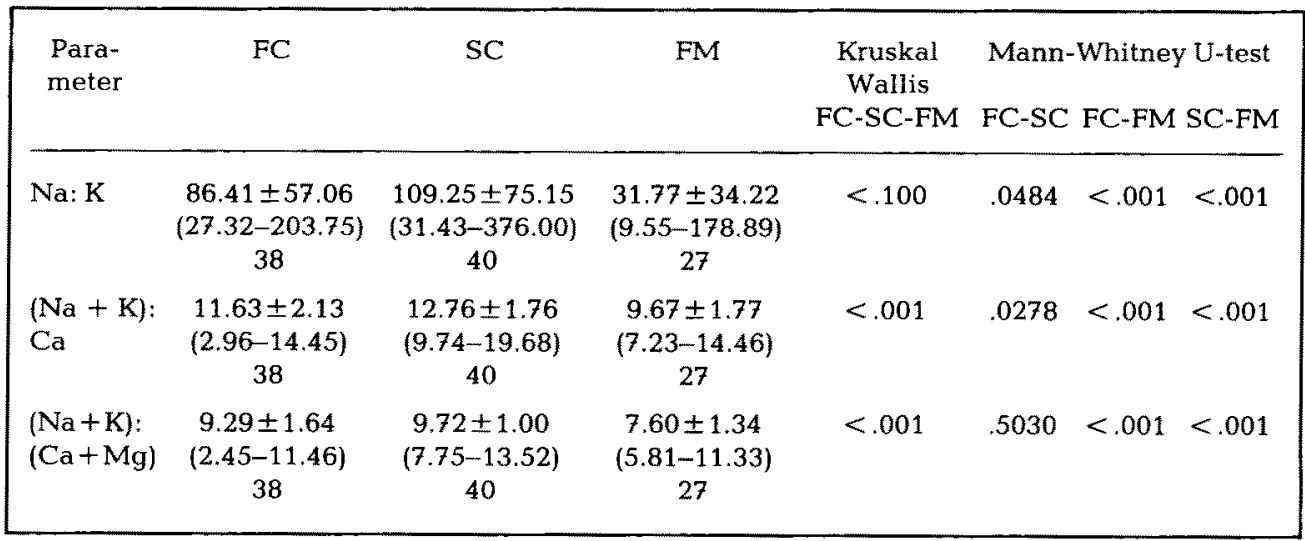

Table 6. Mean, standard deviation and range of muscle electrolyte ratios in three categories of maturing eels, freshwater controls (FC), sea water controls (SC) and moribund eels (FM), and probability levels of homogeneous means or distribution between these categories

\begin{tabular}{|lccccccc|}
\hline $\begin{array}{l}\text { Para* } \\
\text { meter }\end{array}$ & FC & SC & FM & $\begin{array}{c}\text { Kruskal } \\
\text { Wallis } \\
\text { FC-SC-FM }\end{array}$ & FC-SC FC-FM SC-FM \\
\hline $\mathrm{Na}: \mathrm{K}$ & $0.27 \pm 0.08$ & $0.28 \pm 0.05$ & $0.31 \pm 0.07$ & $<.100$ & .1580 & .0462 & .1730 \\
& $(0.17-0.55)$ & $(0.20-0.41)$ & $(0.15-0.41)$ & & & & \\
& 40 & 39 & 27 & & & & \\
$(\mathrm{Na}+\mathrm{K}):$ & $26.65 \pm 7.88$ & $69.65 \pm 114.0$ & $25.18 \pm 8.64$ & $<.001$ & $<.001$ & .4356 & $<.001$ \\
$\mathrm{Ca}$ & $(15.09-53.52)$ & $(18.11-725.19)$ & $(12.79-53.05)$ & & & \\
& 40 & 39 & 27 & & & & \\
$(\mathrm{Na}+\mathrm{K}):$ & $10.65 \pm 2.08$ & $14.56 \pm 3.67$ & $10.90 \pm 2.57$ & $<.001$ & $<.001$ & .7396 & $<.001$ \\
$(\mathrm{Ca}+\mathrm{Mg})$ & $(7.00-15.70)$ & $(8.79-23.27)$ & $(6.21-17.19)$ & & & & \\
& 40 & 39 & 27 & & & & \\
\hline
\end{tabular}

concentrations were lower by 18 and $22 \%$ in moribund eels. Finally, there was a small reduction in muscle calcium, but that is not statistically significant.

Muscle water content was the same in both categories (Table 4) as were the $\mathrm{Na}: \mathrm{K}$, $(\mathrm{Na}+\mathrm{K}): \mathrm{Ca}$ and $(\mathrm{Na}+\mathrm{K}):(\mathrm{Ca}+\mathrm{Mg})$ ratios. However those ratios were much lower in the blood of moribund eels than in that of freshwater and salt water controls (Table 5 and Table 6).

\section{DISCUSSION}

Their catadromous migration takes the maturing eels from an environment of low salt concentration to an environment of high salt concentration. Freshwater eels must 
make for the penetration of water through their gills. Mineral balance is maintained by renal loss (Sharratt et al., 1964) and, to replace the minerals lost through the kidneys, by the absorption of minerals through the gills (Krogh, 1939; Bellamy \& Chester Jones, 1961; Chester Jones et al., 1962; Motais, 1966) and through the intestine. Passage to salt water results in the loss of water through the gills. This is balanced by the ingestion of salt water, the production of a scanty and highly mineralized urine (Sharratt et al., 1964) and the excretion of salts through the gills (Bellamy, 1961; Motais, 1966; Smith, 1930). Part of the excess sodium and chloride is excreted through $\mathrm{Na} / \mathrm{Na}$ and $\mathrm{Cl} / \mathrm{Cl}$ exchanges in the gills. The rate of exchange is a function of sodium and chloride concentrations in the environment. However, this is not so in the case of the hormonally-controlled excretion of sodium and chloride in the maturing eels (Motais, 1966).

The hormonally-controlled mechanisms that regulate ion concentration in maturing eels in salt water, are set up in freshwater as part of the processes of maturation (reviewed by Fontaine, 1975). Transfer of maturing eels to salt water in laboratory conditions resulted in limited increases in the plasma osmotic concentration and in the plasma and muscle ion concentrations, and in limited decreases in the proportion of water in muscle (Homes \& Donaldson, 1969; Love, 1970). The changes measured in this study between the freshwater controls and the salt water controls in the field corroborate these conclusions. Some of the maturing eels however fail to maintain their mineral balance in freshwater as shown by the extremely low serum osmolality of moribund eels $(270 \mathrm{mOsm} / \mathrm{kg})$. This concurs to explain their passivity (Bertin, 1956; Fontaine, 1975). This value is close to that measured by Schmidt-Nielsen \& Renfro (1975) in starved Anguilla rostrata, and is much lower than measured in the freshwater controls (328 $\mathrm{mOsm} / \mathrm{kg}$ ), or in $A$. anguilla (346 $\mathrm{mOsm} / \mathrm{kg}$ ) by Portier \& Duval (1922). That low value resulted from a marked loss of sodium and more particularly chloride, and a concurrent increase in extracellular potassium in the blood. Magnesium and calcium concentrations in serum are not relevant parameters in this context. Though the percentage water remained constant, the muscle electrolyte concentrations decreased in general except chloride that markedly increased in moribund eels. The mechanism for that increase is not known.

There is a remarkable variation in mean length between the freshwater controls and the salt water controls. This is the result of length-related variations in distribution or in time of migration to sea, or of variability in gear selectivity between St. Nicolas and Kamouraska. Diseased eels behave in a non length-related manner: their mean length is half way between those of freshwater and salt water controls and their lengths are much more variable.

These results, particularly as concerns the very low chloride concentration in the blood of moribund eels, substantiate the contention that mortality must be related to the failure in some of the maturing eels to maintain their mineral balance in the natural situation (Tucker, 1959). Should the catadromous migration start from remote locations or be blocked by physical or chemical barriers, the hormonally-controlled processes could result in excessive mineral loss. There is no mechanism in the eel to take up chloride through the gills (Krogh, 1937; Motais, 1966) and there is no nutritional gain of chloride in maturing eels due to physiological fast. There are also indications that chloride cells (the cells responsible for the excretion of excess $\mathrm{NaCl}$ in salt water) proliferate as the maturing eel is still in freshwater (Fontaine, 1975). The histological 
examination of the gill lamellae has recently shown the chloride cells to be present in the diseased eels but not in the healthy eels in fresh water (Dutil, in prep.).

The mechanism that links mineral loss to mortality is not known. However, maturation is known to be reversible. Thus maturing eel mortalities such as take place in the St. Lawrence Estuary are not common. The solution calls for a third variable related to maturation in freshwater. Mineral loss could be the intermediate in a series of physiological disorders resulting in mortality, or mineral loss could be the releasing mechanism that results in mortality through intermediate physiological disorders in the particular conditions that prevail in the St. Lawrence Estuary.

Acknowledgements. I thank F. Gingras and M. Ouellet, fishermen in St. Nicolas and Kamouraska, for the collection of eels. M. Fortin dissected the eels for analysis and made the biological measures on the specimens. Electrolyte concentrations were measured by the Institut de bioendocrinologie of Montreal (blood analysis) and the Laboratoire régional de Longueuil of the Department of Fisheries and Oceans, Government of Canada (muscle analysis). I thank Dr. R. M. MacKelvie, R. L. Saunders and two referees for their constructive criticisms.

\section{LITERATURE CITED}

Bellamy, D., 1961. Movements of potassium, sodium and chloride in incubated gills from the silver eel. - Comp. Biochem. Physiol. 3, 125-135.

Bellamy, D. \& Chester Jones, I., 1961. An apparatus for studying the gain and loss of electrolytes by the eel. - Comp. Biochem. Physiol. 3, 223-226.

Bertin, L., 1956. Eels, a biological study. Cleaver-Hume Press, London, 192 pp.

Chester Jones, I., Phillips, J. G. \& Bellamy, D., 1962. Hormones affecting environmental adjustment. Studies on water and electrolytes in cyclostomes and teleosts with special reference to Mixine glutinosa and Anguilla anguilla. - Gen. comp. Endocrinol. Suppl. 1, 36-47.

Fontaine, M., 1975. Physiological mechanisms in the migration of marine and amphihaline fish. Adv. mar. Biol. 13, 241-355.

Holmes, W. N. \& Donaldson, E. M., 1969. The body compartments and the distribution of electrolytes. In: Fish physiology. Ed. by W. S. Hoar \& D. J. Randall. Acad. Press, New York, 1, 1-90.

Krogh, A., 1937. Osmotic regulation in freshwater fishes by active absorption of chloride ions. $-Z$. vergl. Physiol. 24, 656-666.

Krogh, A., 1939. Osmotic regulation in aquatic animals. Cambridge Univ. Press, London, 242 pp.

Love, R. M., 1970. The chemical biology of fishes. Acad. Press, London, 547 pp.

Motais, R., 1966. Les mécanismes d'échanges ioniques branchiaux chez les téléostéens: leur rôle dans l'osmorégulation. - Annls. Inst. océanogr., Monaco, 45, 1-84.

Portier, P. \& Duval, M., 1922. Variation de la pression osmotique du sang de l'anguille en fonction des modifications de salinité du milieu extérieur. - C. r. Séanc. Soc. Biol. 175, 324-326.

Siegel, S., 1956. Nonparametric statistics for the behavioral sciences. McGraw-Hill, New York, $312 \mathrm{pp}$.

Schmidt-Nielsen, B. \& Renfro, J. L., 1975. Kidney function of the American eel Anguilla rostrata. Am. J. Physiol, 228, 420-431.

Sharratt, B. M., Chester Jones, I. \& Bellamy, D., 1964. Water and electrolyte composition of the body and renal function of the eel (Anguilla anguilla). - Comp. Biochem. Physiol. 11, 9-18.

Smith, H. W., 1930. The absorption and excretion of water and salts by marine teleosts. - Am. J. Physiol. 93, 480-505.

Tucker, D. W., 1959. A new solution to the Atlantic eel problem. - Nature, Lond. 183, 495-501. 